\title{
Resources, Capabilities and Entrepreneurial Perceptions*
}

\section{Yasemin Y. Kor, Joseph T. Mahoney and Steven C. Michael}

University of South Carolina; University of Illinois at Urbana-Champaign; University of Illinois at Urbana-Champaign

ABSTRAGT We review and develop a subjectivist theory of entrepreneurship that focuses on individuals, their knowledge, resources and skills, and the processes of discovery and creativity, which constitute the heart of entrepreneurship. First, we establish the fundamental importance of subjectivity in entrepreneurial discovery and creativity. Second, we build on Penrose (1959) to elaborate how entrepreneurs' perceptions and personal knowledge shape a firm's subjective productive opportunity set. Third, we explain that entrepreneurial perceptions and knowledge partly originate from entrepreneurs' experiences in specific business settings such as the firm, the management team, and the industry. Fourth, we highlight the causal connections between subjectivity in entrepreneurship and observed heterogeneity in firm-level economic performance. Lastly, we suggest directions for further advancing a subjectivist resource-based approach to future entrepreneurship research.

\section{INTRODUCTION}

Entrepreneurship is fundamentally important to firms and government agencies worldwide. Indeed, entrepreneurship is the core of the dynamics of modern capitalism, and the entrepreneur is 'the driving force of the whole market system' (Mises, 1998, p. 249). Entrepreneurship typically liberalizes the economy, promotes foreign investment, infuses new technology, and increases economic standards of living (Barringer and Bluedorn, 1999; Bygrave, 1998; Leff, 1979; McDougall and Oviatt, 2000; Zahra et al., 2000). Understanding better how entrepreneurship enhances the economic development of poorer nations and creates economic wealth within developed nations requires increased effort by researchers, especially within an institutional context (George, 2000; Phan, 2004; Saravathy, 2004; Zahra, 2005).

This research paper adopts a broad definition of the entrepreneur (Low and MacMillan, 1988), which parallels that of Penrose (1959) and includes the distinctly 
purposeful human action of individuals or groups within any firm providing essential innovative services regardless of their organizational position. Conceptually, the entrepreneur need not be as dramatic as the one described by Schumpeter $(1934),{ }^{[1]}$ in which the entrepreneur offers an innovation that is new to the economy, but rather it is sufficient that the entrepreneur offers an innovation that is new to the firm (Baumol, 1990; Penrose, 1959).

Entrepreneurial employees can provide a wide range of entrepreneurial services to their firm including generating and evaluating innovative ideas related to products, technology, and administrative organization, financing of firm-level activities, and guiding the direction and governance of a firm's growth (Klein, 1999). This proposed definition of entrepreneurship goes beyond the limited focus on entrepreneurship through new products to include novelty in entrepreneurial activities of the organization such as innovation in organizational design, leadership, and financing (Daily et al., 2002). ${ }^{\left[{ }^{[2]}\right.}$ As Hayek (1948) emphasized, an economy consists of myriad facts in time and in space. An innovative idea can only be new to the world once, but such an idea can be innovative and uniquely valuable to firms or customer groups at different points in time and still create substantial utility. Pragmatically, a broader definition of entrepreneurship allows for greater recognition of the wide range of innovative activities in organizations, where entrepreneurship occurs through subjective processes of discovery, learning, and creativity (Penrose, 1959).

The current paper further develops Mahoney and Michael's (2005) subjectivist theory of entrepreneurship, which brings together elements of individual creativity, discovery, surprise, and learning. A subjectivist theory of entrepreneurship deals constructively with both individual creativity and the stochastic nature of knowledge-creation processes (Boettke, 2002; O'Driscoll and Rizzo, 1985). Such a subjectivist theory rejects orthodox neoclassical microeconomic theory's strict definition of perfect economic rationality where actors engage in predictable moves on the basis of well-defined choice sets. Indeed, we embrace the Austrian economics (and existentialist) proposition that the future is not merely unknown, but unknowable. ${ }^{[3]}$

Business decisions in historical (or real) time are rarely made with complete knowledge of their consequences. In dealing with uncertainties, decision makers are 'boundedly rational' (Simon, 1947), and such decision makers enact routines and standard operating procedures, at least in part, for the purpose of achieving effective coordination (Cyert and March, 1963). In a world of genuine (irreducible) uncertainty (Knight, 1921; Loasby, 1976) and subjectivity in decision making and creativity, holding on to the assumption of perfect economic rationality 'as the traditional theory does, is to hide an essential thing and to ignore a fact which, in contrast with other deviations of our assumptions from reality, is theoretically important and the source of the explanation of phenomena which would not exist without it' (Schumpeter, 1934, p. 80).

A subjectivist perspective of entrepreneurship emphasizes the non-deterministic, evolutionary nature of dynamic capabilities and entrepreneurial activities. Search outcomes, in particular, are partly stochastic. In Nelson and Winter's evolutionary theory of the firm, 'firms are modeled as simply having, at any time, certain capabilities, and decision rules. Over time these capabilities and rules are modified as a result of both deliberate problem solving efforts and random events. And over time, the economic analogue of natural selection operates as the market determines which firms are profitable and which 
are unprofitable, and tends to winnow out the latter' (Nelson and Winter, 1982, p. 4). The nature of our experience of time is such that the pattern of knowledge is continually changing. It is inconceivable that our knowledge would not change over time, and such change will often be accompanied by surprises. Time and knowledge belong together. The 'surprise' element is at the heart of the life of an entrepreneur, and the detection of errors and learning are an integral component of 'entrepreneurial discovery' (Kirzner, 1973; Shane, 2000). A subjectivist perspective of entrepreneurship is consistent with an Austrian economics approach where: 'the notion of discovery, midway between that of the deliberately produced information in standard search theory, and that of sheer windfall gain generated by pure chance, is central' (Kirzner, 1997, p. 72).

By grounding the theory of entrepreneurship in subjectivism (Hayek, 1955; Lachmann, 1986; Machlup, 1982; Mises, 1998; Shackle, 1972; Yeager, 1987, 1994), ${ }^{[4]}$ the current paper highlights the subjective nature of entrepreneurial discovery and creativity, and builds on Penrose's (1959) resources approach to establish links between entrepreneurial creativity and intuition and entrepreneurial knowledge. As Penrose states: 'the decision to search for opportunities is an enterprising decision requiring entrepreneurial intuition and imagination and must precede the "economic" decision to go ahead with the examination of opportunities for expansion' (Penrose, 1959, p. 34). Consideration of creativity and imagination enlighten our understanding of the wellsprings of entrepreneurial activities (Buchanan and Di Pierro, 1980). Building on Penrose's (1959) subjective resource-based approach, we consider the dynamic processes that influence the development of entrepreneurial heuristics and business intuitions based on entrepreneurs' experiences and knowledge, which are distributed, tacit and subjective (Spender, 1989; Tsoukas, 1996; Zander, 2007).

This research paper consists of five sections. First, we establish the importance of subjectivity in entrepreneurial discovery and creativity. The development of a subjectivist theory of entrepreneurship makes clear that the substantial role of entrepreneurs involves not only discovering available profitable opportunities but also the endogenous creation of previously unknown economic opportunities through inter-divisional knowledge spillovers (Audretsch and Keilbach, 2007) as well as interactions with customers, technologies, and other stakeholders.

Second, we build on Penrose (1959) to elaborate how entrepreneurs' subjective perceptions and personal knowledge (Polanyi, 1962) can shape a firm's subjective productive opportunity set. The economic consequences of a subjective productive opportunity set is that there is uniqueness not only in the set of productive opportunities each firm can pursue successfully, but also in the rate at which a firm can profitably seize these opportunities.

Third, we explain that subjective entrepreneurial perceptions and knowledge often originate from entrepreneurs' experiences in specific business settings such as the firm, the management team, and the industry. This section develops a theory of the impact of firm-specific, team-specific, and industry-specific experiences on subjective entrepreneurial perceptions and knowledge.

Fourth, we highlight the causal connections between subjectivity in entrepreneurship and observed heterogeneity in firm-level economic performance. The heterogeneity of economic performance among firms is posited to be, at least in part, a direct result of the 
heterogeneity of entrepreneurial beliefs and the heterogeneity of other resources and capabilities of firms, as well as the idiosyncratic deployment of these resources and capabilities.

Lastly, we suggest directions for a subjectivist resource-based approach to future entrepreneurship research. We anticipate that better integration of entrepreneurship and strategic management research literatures will contribute greatly to the evolving science of organization.

\section{SUBJEGTIVITY IN ENTREPRENEURIAL DISGOVERY AND GREATIVITY}

Subjectivist entrepreneurial discovery takes place as entrepreneurs seek to seize the opportunities afforded by market frictions, such as uncertainties in competitive and technological conditions, which are typically not known in advance, and may only be resolved over time. Entrepreneurs' interactions with customers, technologies, and firms lead to a discovery procedure (Hayek, 1968; Lewin and Phelan, 1999; Salerno, 1993), which is then put to the market test. The market test sorts out which entrepreneurial frameworks and ideas are workable in the world of experience (Klein and Klein, 2001; Malmgren, 1961). The entrepreneur in the market system is an innovator who turns information into potentially socially useful knowledge. In turn, the market system provides a trial-and-error process, which enables such entrepreneurial experimentation within a complex competitive landscape that is typically in disequilibrium (Metcalfe, 2004; Nelson and Winter, 1982; Penrose, 1959). Consistent with the subjectivist perspective, Schumpeter suggests that entrepreneurial success depends on intuition, the capacity of seeing things in a way which afterwards proves to be true, even though it cannot be established at the moment and of grasping the essential fact, discarding the unessential, even though one can give no account of the principles by which this is done' (Schumpeter, 1934, p. 85).

Boulding notes that: 'We are not simply acquiring knowledge about a static system which stays put, but acquiring knowledge about a whole dynamic process in which the acquisition of knowledge is itself part of the process [of discovery]' (1966, p. 9). Relatedly, Kirzner argues that: 'human action involves a posture of alertness toward the discovery of as yet unperceived opportunities and their exploitation' (1979, p. 109). It is important to note that entrepreneurial discovery can occur as a coherent 'spontaneous ordering' (Hayek, 1978, p. 34) that transcends inherent limits of individual knowledge and emerges from market interactions of various entrepreneurial activities (Lewin, 2001; Vaughn, 1999). Such spontaneous ordering is a human social organization of entrepreneurial activities, which is understood as: 'the result of human action but not of human design' (Hayek, 1948, p. 7). In a subjectivist perspective of entrepreneurship, a given external environment does not strictly determine decision-making alternatives and choices. There are substantial possibilities for the creativity and autonomy of individual choice (Cole, 1978; Penrose, 1959). Entrepreneurial discovery and creativity serve a coordination role, where entrepreneurial attempts to create new business models yield a network of entrepreneurial interactions that constitute the 'marvel' (Hayek, 1948, p. 87) of the market process. It is a process whereby anyone's entrepreneurial contribution is put to the market test and, where found lacking, may be corrected by other entrepreneurs. Within 
such a dynamic process, coordination emerges as a creative entrepreneurial act (Barnard, 1938; Hayek, 1948; O’Driscoll, 1977).

Further, a subjectivist theory of entrepreneurship suggests a causal link between entrepreneurial creativity and how entrepreneurs learn from dynamics in various market processes (Barreto, 1989; Baumol, 1978, 1993). Hayek notes that competitive dynamics involves 'a process of the formation of opinion . . . a process which involves a continuous change in the data and whose significance must therefore be completely missed by any theory which treats these data as constant' (1948, p. 94). Market dynamics act as economically valuable exploration opportunities for the entrepreneur (McGrath, 2001). As Hayek explains: 'Competition is valuable only because, and so far as, its results are unpredictable and on the whole different from those which anyone has, or could have, deliberately arrived at' (1978, p. 180). Various entrepreneurs in an organization collectively influence an organization's learning as these entrepreneurs discover, learn, create and enact new entrepreneurial opportunities during interactions with an ever-changing and unpredictable business environment (Witt, 1998). Organizational learning occurs through an evolutionary discovery procedure guided by entrepreneurs' new images of potential entrepreneurial opportunities and innovative interpretive frameworks for handling new types of business problems (Penrose, 1959; Prahalad and Bettis, 1986). The process of organizational learning as a collective phenomenon allows the exchange of ideas and knowledge among individuals and widens a firm's collective imagination concerning viable productive entrepreneurial opportunities (Holcombe, 2003; Ionnanides, 1999; Witt, 1999; Zahra and Filatochev, 2004). ${ }^{[5]}$

Further, from a subjectivist perspective not only is there entrepreneurial discovery of existing opportunities (Jacobson, 1992), but also entrepreneurial creativity, whereby entrepreneurs create economically profitable opportunities through their interactions with customers, technologies, and other stakeholders (Ardichvili et al., 2003; Buchanan and Vanberg, 1991; Busenitz, 1996; Gifford, 1992, 1998; Kaish and Gilad, 1991; Minniti, 2004; Sorensen and Sorenson, 2003; Yu, 2001). Entrepreneurs not only respond to changes in the business environment, but also create change (Alvarez et al., 2005). Such entrepreneurs seek to influence and create new demand through innovative products and services, advertising, and personal charisma. Astute entrepreneurial judgment goes beyond vivid imagination, good insights, and self-confidence. It also involves 'organization of information-gathering and consulting facilities within a firm, and it leads into the whole question of the effects of uncertainty on, and the role of expectations in, the growth of firms' (Penrose, 1959, p. 41). Entrepreneurship requires devising and discovering markets and accurately evaluating alternative product opportunities and techniques (North, 1990; Penrose, 1959).

In addition, in creating new economic opportunities, entrepreneurs seek resources to develop these opportunities. Entrepreneurs often engage in risk taking to utilize an opportunity with fewer resources than other decision makers can imagine will prove adequate (Stevenson and Jarillo, 1990). Entrepreneurial energies and individuals' ambitions lead to experimentation with new business activities - e.g. exploring the possibilities of a new value-chain business model (Jacobides and Winter, 2007) - within a competitive landscape that is typically in disequilibrium. Entrepreneurship not only involves willingness to take risks, but also includes intelligent searching for new ways of avoiding 
unnecessary risks while still achieving a substantial positive rate of firm-level growth, when profitable opportunities are available (Cyert and March, 1963; Penrose, 1959; Rubin, 1973). Entrepreneurship involves possessing subjective visions about business opportunities and mobilizing resources and capabilities to turn entrepreneurial visions into business reality (Choi and Shepherd, 2004; Shepherd and DeTienne, 2005; Stuart and Sorenson, 2005; Witt, 2007). ${ }^{[6]}$

Due to asymmetric information and tacit knowledge many viable new business ventures lack sufficient financial funds to make substantial capital investments that are essential for growth. Yet, these ventures still succeed and grow into large firms because of the organizational capability to attract the necessary financial support for these entrepreneurial ventures. Penrose notes that: 'there are many examples testifying to the ingenuity of the superior businessmen in obtaining the funds he needs, and only if the requisite entrepreneurial ability is lacking can one safely say that a firm cannot attract the required capital' (1959, pp. 37-8). With personal experience and knowledge, many entrepreneurs find creative ways to fund new business ideas even in mature product and service markets (e.g. through franchising (Bercovitz, 1999; Michael, 2000)). The relevance of entrepreneurs' personal knowledge to entrepreneurs' subjective perception and choices is anticipated in Penrose's (1959) 'resources approach', to which we now turn our attention.

\section{ENTREPRENEURS' PERGEPTIONS AND KNOWLEDGE AND PENROSE'S (1959) RESOURGES APPROACH}

Concerning entrepreneurs' perceptions and knowledge, fundamental insights from Penrose's (1959) subjectivist resources approach prove quite useful. Penrose emphasizes the important conceptual distinction between resources and the services of resources noting that: "Strictly speaking, it is never resources themselves that are the "inputs" in the production process, but only the services that the resources can render. ... [R] esources consist of a bundle of potential services and can, for the most part, be defined independently of their use, while services cannot be so defined, the very word "service" implying a function, and activity. ... [I]t is largely in this distinction that we find the source of the uniqueness of each individual firm' (Penrose, 1959, p. 25). This conceptual distinction is crucial because the causal linkage between resources and the services of these resources occurs because of the subjective perceptions of the entrepreneur.

Penrose also states that 'the productive activities of such a firm are governed by what we shall call its "productive opportunity", which comprises all of the productive possibilities that its "entrepreneurs" see and can take advantage of' (1959, p. 31). Because resources and the services of these resources differ for each entrepreneur in a subjective manner, each individual's perceived productive opportunity set differs from others. Due to the subjectively perceived multiple uses of a specific resource and the heterogeneous subjectively envisioned combinations of resources there exists a large number of possibilities for entrepreneurial choices and activities, which in turn produces different firmlevel economic performance outcomes.

Essentially, Penrose's disequilibrium 'resources approach' (1959, p. 217) focuses on the relationship "not only between the "inherited" resources of a firm and the ability of 
the firm to take advantage of the opportunities perceived by its entrepreneurs, but also between these resources and the perceptions of the entrepreneurs' (1959, p. 216). A firm's pool of unused productive services of resources interacts with the evolving vision of entrepreneurs to create the subjective productive opportunities for each firm. ${ }^{[7]}$ Ulti- $^{\text {i }}$ mately, entrepreneurs' perceptions become a major driver of firm-level heterogeneity and differential absorptive capacity (Cohen and Levinthal, 1990; Kor and Mahoney, 2004; Wiklund and Shepherd, 2003). Likewise, Casson notes that: 'The entrepreneur believes he is right while everyone else is wrong. Thus, the essence of entrepreneurship is being different - being different because one has a different perception of the situation' (1982, p. 14). In the business context of entrepreneurial decision-making under uncertainty, there is an incomplete market for business judgment, which typically is made even more complicated due to potential opportunism and moral hazard problems (Barzel, 1987; Casson and Godley, 2007; Foss, 1994; Foss and Foss, 2005; Foss et al., 2007; Knight, 1921; Witt, 2007). ${ }^{[8]}$

Unlike neoclassical microeconomics treatments of entrepreneurship (e.g. Demsetz, 1983), which typically posit demand as exogenously determined by environmental forces, Penrose's (1959) resources approach recognizes the close connection between the entrepreneur and the opportunities the environment 'offers' to the firm. The entrepreneur's subjective perception of such opportunities is closely linked to the perception of economic demand. Penrose observes that: 'The really enterprising entrepreneur has not often, as far as we can see, taken demand as "given" but as something he ought to be able to do something about' (1959, p. 80). In fact, Penrose submits that: 'There is a close relation between the various kinds of resources with which a firm works and the development of the ideas, experience, and knowledge of its managers, and entrepreneurs, and we have seen how changing experience and knowledge affect not only the productive services available from resources, but also "demand" as seen by the firm' (1959, p. 85). Thus, the subjectivity of the entrepreneurial opportunities envisioned by the entrepreneur stems, at least in part, from the entrepreneur's personal knowledge of the firm's unique bundle of resources and capabilities.

The economic importance of the entrepreneur's personal knowledge (Polanyi, 1962) comes to the foreground of a subjectivist entrepreneurial theory. Entrepreneurship typically requires personal (i.e. experiential) knowledge of the firm's resources and inner workings, and the knowledge of the competitive market. Such experiential knowledge is subjective, and needs to be discovered (Dulbecco and Garrouste, 1999; Menger, 1985), as different people discover different things or put different interpretations on what they discover (Mises, 1998; Shackle, 1961). Entrepreneurs' personal knowledge is viewed as subjective not only because different entrepreneurs produce different combinations of knowledge, but also these entrepreneurs interpret and enact such new combinations of knowledge in unique ways (Lachmann, 1986). Even when operating with the same resources, different individuals may generate entirely different services from these resources (Penrose, 1959).

The versatility and subjectivity of entrepreneurial knowledge and insight help explain the persistence of firm-level heterogeneity in entrepreneurial activities. Penrose notes that: 'A versatile type of [entrepreneurial] service is needed if expansion requires major efforts on the part of the firm to develop new markets or entails branching out into new 
lines of production. Here the imaginative effort, the sense of timing, the instinctive recognition of what will catch on or how to make it catch on become of overwhelming importance. These [entrepreneurial] services are not likely to be equally available to all firms' (1959, p. 37).

A firm's idiosyncratic resources and organizational capabilities can greatly influence the entrepreneur's 'image' and expectations of the future (Boulding, 1956) and consequently can serve as cognitive drivers of future strategy via 'resource learning' (Spender, 1996). The cognitive models held by a firm's leaders typically play a critical role in directing the path of the resource accumulation process and resource learning (Barr et al., 1992). Resources are the stock, while learning constitutes the flows, of a firm's 'combinative capabilities' (Ahuja and Lampert, 2001; Dierickx and Cool, 1989; Kogut and Zander, 1992).

Combining knowledge in creative ways yields entrepreneurial activities (Bull and Willard, 1993; Hagedoorn, 1996). Schumpeter (1934) notes that the entrepreneur develops new combinations of economic value creation activities: 'This concept covers the following five cases: (1) the introduction of a new good . . . or a new quality of good. (2) The introduction of a new method of production...(3) The opening of a new market ... (4) The conquest of a new source of supply of raw materials . . . [and] (5) The carrying out of the new organization of any industry ...' (1934, p. 66). According to Schumpeter (1934), the creative act of formulating new knowledge combinations is fundamentally different from following standard operating procedures. Specifically, Schumpeter states that: 'Carrying out a new plan and acting according to a customary plan are things as different as making a road and walking along it' (1934, p. 85). Imagining new combinations of economic value creation activities and resources is at the heart of entrepreneurial creativity and the development of dynamic capabilities (Zahra et al., 2006). ${ }^{[9]}$

In addition, entrepreneurs' personal knowledge and perceptions influence the rate and direction of the growth of a firm. The services imaginable from a firm's bundle of resources depend upon the entrepreneurial vision of the top management team, but the development of this entrepreneurial vision is also affected by the unused productive services of resources. Unused productive services of resources shape 'the scope and direction of the search for knowledge' (Penrose, 1959, p. 77). As the entrepreneur's subjective perceptions and the productive services of firm's resources shape each other and evolve together, so does the subjective vision about future directions of firm-level growth (Mahoney and Pandian, 1992). In fact, a firm's rate of growth will also be limited by the capacities of the existing managerial and entrepreneurial resources because management possessing firm-specific knowledge cannot be hired in the external labour market (Tan and Mahoney, 2005; Teece, 1982). There is uniqueness not only in the set of productive opportunities each firm can pursue successfully, but also in the rate at which a firm can profitably seize these opportunities.

Given the substantial role of subjective entrepreneurial perceptions and knowledge for identification and development of a unique productive opportunity set for the firm, it should be useful to consider their origins. Understanding better the sources of the entrepreneurs' subjective perceptions and knowledge may help us to better explain and predict the path that firms will take in the course of decision making under uncertainty. 
Penrose notes that: 'if we can discover what determines entrepreneurial ideas about what the firm can and cannot do, that is, what determines the nature and the extent of the "subjective" productive opportunity of the firm, we can at least know where to look if we want to explain or to predict the actions of particular firms' (1959, p. 42).

The entrepreneurial character of an individual including the sense of direction (intuition), risk-willingness, and coordination of successful experiments (Eliasson, 1990) is influenced by a variety of experiences that this individual possesses. Thus, we next consider how the subjective entrepreneurial perceptions and personal knowledge may originate from entrepreneurs' specific experiences in various contexts such as the firm, the team, and the industry. Given the limited availability of entrepreneurial services in firms, examining different characteristics and sources of entrepreneurs' subjective perceptions and knowledge generates new insights about how entrepreneurs adapt and respond to changing environmental conditions.

\section{IMPACT OF ENTREPRENEURS' EXPERIENGE ON THEIR SUBJECTIVE PERGEPTIONS AND KNOWLEDGE}

During the entrepreneurial process, entrepreneurs acquire non-theoretical (i.e. experience-based) 'knowledge of the particular circumstances of time and place' (Hayek, 1945, p. 521), and such knowledge often involves tacitness (Polanyi, 1962). Discovering markets and accurately evaluating product markets and technologies involve the development of tacit knowledge. North suggests that: 'The (political or economic) entrepreneurs may devote their talents or tacit knowledge to ferreting out profitable margins, estimating the likelihood of success, and risking the organization's resources to capture potential gains. Obviously, the efficiency of organizations depends on perceiving and realizing these opportunities' (1990, p. 87). Strategically, this tacitness of the entrepreneurs' knowledge is an invisible (intangible) asset (Itami and Roehl, 1987) and can be an important source of sustainable competitive advantage for the firm due, at least in part, to causal ambiguity and uncertain imitability (Rumelt, 1987). Thus, in this section, we focus on how entrepreneurs' experiences in specific business settings such as the firm, the management team, and the industry may impact their subjective entrepreneurial knowledge and perceptions. We continue to argue that entrepreneurship can occur at any level in the organization, yet consistent with Penrose's (1959) resources approach, we give close attention to the entrepreneurial services provided by the firm's managers and the importance of their personal experiences in shaping their capacity to provide these services.

\section{Firm-Specific Experience}

Experience in a particular firm enables managers to develop intimate and tacit knowledge of the firm's resources, capabilities, operations, unique historical conditions, and standard operating procedures. Managers build firm-specific knowledge over time as a result of historical interactions with the firm's resources and management team members (Penrose, 1959). Because firms renew and develop their resource and capability bundles through path-dependent processes, firms typically benefit from managers with tacit 
knowledge of the firm's material, human, and intangible resources (Kor, 2003). For example, managers' tacit knowledge of the firm's employees enables these managers to match more effectively their employees' skills to particular jobs, and employees can be matched better to each other in team settings (Prescott and Visscher, 1980). Firm-specific knowledge may constitute an important part of managers' entrepreneurial capital since compared to new firm-level managers those managers possessing firm-specific experience may accurately envision a superior subjective productive opportunity set for the firm (Kor and Mahoney, 2000). This outcome may occur because managers' historic and intimate knowledge of the firm provides these more experienced managers with the appropriate conceptual lenses to better identify the entrepreneurial opportunities a firm should pursue. These managers can assess more precisely the opportunities in the environment that fit with the firm's internal strengths and weaknesses (Andrews, 1980). A specialized base of resources and services of these resources may have considerable economic value; however, only with the experiential knowledge of the firm's resources can the entrepreneur create these strategic options for further expansion and to increase the firm's absorptive capacity (Kor and Mahoney, 2005).

The development of subjective entrepreneurial insights concerning new productive opportunities involves the pre-condition of intimate familiarity with the firm. Familiarity involves the experiential 'knowledge about the unique characteristics of machinery, physical environment, people, performance strategies, and jobs in a particular section at a particular time' (Goodman and Leyden, 1991, p. 579). With experiential knowledge of the firm, individuals can develop a better understanding of firm policies and organizational language (March and Simon, 1958) and may become more committed to the organization (Kerr and Jackofsky, 1989). Also, firm-specific knowledge and organizational capabilities developed during experience within a specific firm cannot be readily transferred to another firm (Harris and Helfat, 1997; Teece, 1982). As Penrose explains: 'experience produces increased knowledge about things and contributes to "objective" knowledge in so far as its results can be transmitted to others. But experience itself can never be transmitted; it produces a change - frequently a subtle change - in individuals and cannot be separated from them' (1959, p. 53). Therefore, entrepreneurs' experiencebased intimate knowledge of the firm's resources and organizational capabilities may contribute greatly to a hard-to-imitate system of entrepreneurial renewal for the firm.

Despite the substantial economic value of firm-specific experiences, an extensive time period of experience in the same organization may not contribute in a linear way to a firm's capacity of entrepreneurial services. As upper-echelons theory reveals, after early economic success and initial learning, managers (and entrepreneurs) may commit psychologically to business-level and corporate-level strategies with which they are comfortable, and with each passing year, these managers may increasingly believe in the correctness of their worldview (Finkelstein and Hambrick, 1996). Long tenure in the firm may diminish managers' inclination to communicate with outside information sources and to seek or to heed external advice. Managers may become both less perceptive and less receptive to new information, which signals that previously agreed upon or implemented decisions are no longer appropriate. Such managers may lack the agility of mind to formulate and to implement adaptive (or preemptive) changes other than incremental changes or imitative changes (Wiersema and Bantel, 1992). 
Thus, it may not be desirable to have an entrepreneurial team where all members have uniformly high levels of firm-specific experience. Instead, a healthy mix of individuals with different levels of experience in the firm may create more synergistic interactions among managers as the experienced members' historical knowledge of the firm blends with entrepreneurial perceptions of individuals who are relatively new to the firm but who still have important other (business and/or non-business) experiences. Research suggests that better results for innovation are typically achieved when an entrepreneurial team contains different backgrounds and different perspectives (Tushman and O'Reilly, 1997). The most prolific entrepreneurial visions may potentially emerge from combining tacit knowledge of a firm's unique bundle of resources and capabilities with a diverse set of entrepreneurial perceptions about the new economic 'demand' conditions.

\section{Team-Specific Experience}

Experience in the management team involves managers' decision-making and implementation experience as a particular team (Priem, 1990). Managers' experience in functioning together as a team includes discussions and debates on strategic decisions, during which these managers learn each other's strengths, weaknesses, and idiosyncratic habits (Kor, 2003; Penrose, 1959). Team experiences also include taking risks on behalf of the firm, committing economically to certain strategic actions under uncertainty, and winning or losing together as a team (Kor and Mahoney, 2000). While having participated in many teams may help a manager to develop teamwork skills, each team is likely to be unique in its functioning, and the addition of a new member to the team will typically require adjustments for all existing members. As Richardson explains: 'the capabilities of any particular cooperating group - the scope and effectiveness of the activities it can undertake - will depend both on the skills of its members and on their inter-relationships. Irrespective of the contractual arrangements associated with this inter-relationship, is the need for it to be stable enough for members of the group to learn to work with each other' (2002, p. 41). In many business cases, management teams with shared experience are non-substitutable organizational capital (Prescott and Visscher, 1980) because other management teams lack the knowledge of specific circumstances and unique historical conditions in which actions need to be interpreted and subsequently coordinated (Barnard, 1938; Penrose, 1959).

Managers' shared team-specific experience may contribute substantially to a firm's entrepreneurial renewal because such experience can accelerate the team's decision making since the team can focus more time and attention to the particular business problems at hand rather than on group process issues (Eisenhardt and Schoonhoven, 1990). Experiential knowledge of the skills and habits of team members prepares the firm for taking otherwise risky endeavours and saves time in coordination (Kor and Mahoney, 2000). Also, team experience may enhance communication and socialization among team members, promoting reduced goal conflict and lower turnover (Smith et al., 1994). Managers' team-specific experience can be a difficult to imitate source of entrepreneurial success because developing tacit and intimate knowledge about team members involves specificity in time and place (Kor, 2003). Only through interactions within a specific 
team and over time can entrepreneurs collectively accumulate a tacit understanding of the strengths, weaknesses, and idiosyncratic habits of others.

However, high levels of shared experience among managers may lead to a groupthink phenomenon (Allison, 1971; Janis, 1972). Speaking a common language and sharing common values, managers may gradually cease questioning and debating each other when in the process of strategic planning. Groupthink tendencies in management teams and in other entrepreneurial teams can threaten entrepreneurial adaptation and renewal of the firm. In high-velocity environments (Bourgeois and Eisenhardt, 1988), where firms need to refine and redefine their productive opportunity set continuously in response to frequent changes in economic demand, competition, and technology conditions, a free exchange of views among entrepreneurs is typically preferred to conformist thinking (Hambrick, 1995). Strategically, firms need to achieve a balance in promoting a management team that possesses sufficient familiarity with, and confidence in, team members so that entrepreneurial managers are willing to make strategic commitments and take risks under uncertainty (Caplan, 1999; Rothbard, 2004), yet at the same time not end up cultivating conformity and groupthink in the team. Firms may promote such a strategic balance by nurturing moderate levels of shared team experience among team members, while allowing some level of turnover and/or rotation among different entrepreneurial teams.

\section{Industry-Specific Experience}

Subjective entrepreneurial knowledge and perception is also shaped by managerial experiences within a specific industry. Industry-specific experience involves interactions with buyers, suppliers, distributors, and other stakeholders, which produce knowledge about the opportunities, threats, competitive conditions, and governmental regulations that are unique to each industry (Kor, 2003; Mosakowski, 1993; Spender, 1989). Many developments in technology, competitive, and regulatory conditions in an industry follow a path-dependent pattern (Arthur, 1994); thus, historical and experience-based knowledge of the industry can be useful for perception and evaluation of new entrepreneurial opportunities. Industry experience often embeds goodwill with certain customers, suppliers, and industry stakeholders. Experienced managers can capitalize on this goodwill by initiating and securing new business relationships for their current firm. Thus, experience in a specific industry not only provides knowledge concerning how the industry works, but such knowledge may also contribute to the economic success of a new business venture when the experienced entrepreneur can more easily secure resources and business orders for the firm through previous industry connections. Consistent with this logic, empirical research indicates a lower start-up firm-level mortality rate and more successful innovative activities for business ventures founded by entrepreneurs experienced within the industry (Cooper et al., 1994).

The subjective view of entrepreneurship emphasizes that resources gain economic value from their use by customers. The economic value of any entrepreneurial innovation is influenced by a relationship between the buyer and the seller. As a result, the entrepreneurial capability to foresee the potential economic value of any innovation depends upon the number of potential relationships of which the entrepreneur is aware. 
Such relationships can be functional, personal, or social, and these relationships are created and maintained through experiences in a specific industry context.

Despite the advantages of such within-industry experience, it may not be advisable for all managers to be equipped with experience that concentrates solely within a single industry. When the majority of managers have a strong industry orientation, the management team may become entrenched by current industry norms and practices (Geletkanycz and Black, 2001; Hambrick et al., 1993). Rigid commitments to insights from previous industry experience may be counterproductive in high-velocity environments where timely adaptations to changes in economic demand, competition and technological conditions are essential for sustained entrepreneurial development and renewal (Chandler and Hanks, 1994). When the management team is uniformly entrenched with historical views of competitive dynamics and buyer expectations, their perception and imagination of the new entrepreneurial opportunities are more likely to be truncated, if not misguided. Therefore, firms should be cautious about having the entire team of managers with a homogeneous level of industry experience. Because managers with different levels of industry experience will have varying levels of commitment to historical industry trends, such differences are likely to spur healthy conversations and debates concerning new strategic directions for the firm. Also, when managers are exposed to inter-industry differences in technology, distribution, marketing, and pricing, they are more likely to be innovative in formulating and implementing new strategies and to position current and future products and services creatively.

\section{SUBJECTIVITY IN ENTREPRENEURSHIP AND FINANGIAL PERFORMANGE}

The heterogeneity of economic performance among firms is posited to be, at least in part, a direct result of the heterogeneity of entrepreneurial beliefs and the heterogeneity of other resources and capabilities of firms, as well as the subjective deployment of these resources and capabilities (Penrose, 1959). Alvarez and Busenitz observe that: 'heterogeneity is a common attribute of both resource-based and entrepreneurship theory although resource-based logic has tended to focus on heterogeneity of resources while entrepreneurship theory has tended to focus on heterogeneity in beliefs about the value of resources' (2001, p. 756). Frequently, entrepreneurial economic profits are created because different decision-makers have different beliefs about the relative economic value of the entrepreneurial opportunities associated with resources and new resource combinations (Penrose, 1959; Schumpeter, 1934; Vaughn, 1994). Indeed, Audretsch maintains that: ' $[\mathrm{I}] \mathrm{t}$ is the uncertainty inherent in new economic knowledge, combined with asymmetries across agents with respect to its expected value, that potentially leads to a gap between the valuation of that knowledge' (1995, p. 39).

Contemporary resource-based theory addresses the business conditions under which resources can yield differential long-run economic performance advantages. Specifically, resources yield superior economic performance if resources are valuable, rare, imperfectly imitated and non-substitutable (Barney, 1991). Imitation is made more difficult by increased causal ambiguity (Rumelt, 1984), which occurs when the organization that desires to imitate the economically successful firm is uncertain concerning the transfor- 
mational processes through which firm's resources are converted into profit-generating capabilities. Attempts at imitation to replicate closely another firm's competitive advantage is also mitigated through social complexity (Barney, 1991), which can occur when individuals and their skills are combined through organizational routines, working relationships, and teamwork experiences that collectively form a distinct corporate culture.

Amit et al. (1990, 1993) emphasize the need for a theory of heterogeneity of entrepreneurial opportunities within a dynamic resource-based theory. Similarly, Mosakowski maintains that: 'Traditional research on the resource-based view of strategy has generally ignored the wide range of human choices and behaviors involved in identifying, leveraging, and creating resources' (2002, pp. 106-7). Recently, however, some progress along these research lines has been made. For example, contemporary resource-based research has begun to highlight the entrepreneur's role in firm-level strategy (e.g. Alvarez and Barney, 2000, 2004; Mosakowski, 1998). Alvarez and Barney argue that: 'Indeed, it may be by examining the intersection between entrepreneurship and the resource-based view (RBV) that clarity may be achieved with regard to the larger impact of entrepreneurship on strategic management' (2002, p. 89).

Further, by examining the dynamics between entrepreneurship and the resourcebased approach, Alvarez and Busenitz (2001) develop a theory of entrepreneurship that builds on Peteraf's (1993) four cornerstones of competitive advantage: resource heterogeneity (Barney, 1991), ex post limits to competition due to causal ambiguity (Rumelt, 1984), imperfect factor mobility due to non-tradable asset stocks (Dierickx and Cool, 1989), and ex ante limits to competition (Rumelt, 1987). From entrepreneurial opportunity recognition to the capability to organize these resources into a firm and then to the creation of heterogeneous outputs through the firm that are superior to those offered in the market, Alvarez and Busenitz (2001) examine the key role of entrepreneurial resources within dynamic resource-based theory. Moreover, researchers have drawn from the resource-based view of strategy to explain outcomes associated with new business ventures (e.g. Deeds et al., 2000; McGrath, 1995; Thornhill and Amit, 2001).

We suggest that further enrichment of the resource-based theory of entrepreneurship can occur through the theoretical insights from Penrose (1959) concerning entrepreneurial choices and behaviours. We emphasize Penrose's (1959) theoretical insight that a firm's resources alone are not determinative, but rather how the subjective entrepreneurial choices about how the firm develops and deploys its resources create entrepreneurial opportunities and economic rents. Penrose's (1959) resource-based approach when applied to entrepreneurship offers theoretical insights into why there are economic performance differences among entrepreneurs. The linkages between resources and the services of these resources require that the resource-based approach to entrepreneurship be a subjective one. The key elements of such an approach include creativity, information, judgment, and perceived entrepreneurial possibilities. The change in competitive and technology landscapes creates entrepreneurial opportunities for new resources and resource combinations to be discovered and implemented by entrepreneurs.

In bringing together dynamic resource-based theory and entrepreneurship research there needs to be a theoretical unpacking of the concept of resource heterogeneity. For example, Alvarez and Busenitz (2001) consider heterogeneity in terms of entrepreneurial cognition (Barr et al., 1992), entrepreneurial discovery (Kirzner, 1997; Witt, 2000), 
changing market opportunities (Shane and Venkatraman, 2000), and differential capabilities in the coordination of knowledge (Conner and Prahalad, 1996). Looking at resource-based theory through an entrepreneurial lens can extend the boundaries of resource-based theory beyond strategy content research and toward research about disequilibrium processes of strategic decision-making. Table I compares the alternative theoretical approaches for entrepreneurship research. As summarized in this table, Penrose's (1959) resources approach and dynamic capabilities perspectives have their roots in Austrian economics. We submit that Penrose's (1959) resources approach can be particularly fruitful for future entrepreneurship research that embraces a subjectivist view of entrepreneurship where entrepreneurial discovery and creation are subjective and stochastic, and the focus is on both the content and the disequilibrium process of decision- making and implementation.

\section{DIRECTIONS FOR FUTURE RESEARGH AND GONGLUSIONS}

In this research paper, we have emphasized the need for a subjectivist theory of entrepreneurship that focuses on the interrelationships among the subjective visions of entrepreneurs, firm-specific experiences and knowledge, and perceived economic opportunities. We see high potential for new theoretical insights emanating from intellectual connections between strategic management and entrepreneurship research. We have built our theoretical arguments on the seminal work of Penrose (1959), who in important ways anticipated a subjectivist theory of entrepreneurship. Penrose (1959) rejects the standard concept of a production function in which inputs are assimilated as factors of production, in favour of an analytical scheme in which resources become a distinct subject of economic analysis and their application (i.e. deployment) is problematic (Loasby, 2002, p. 52). Creative deployment of a firm's resources can be problematic not only because the economic opportunities to their use have to be perceived or imagined (Shackle, 1967), but also because the effectiveness of a resource to a particular entrepreneurial application can never be guaranteed in advance.

Future research on entrepreneurship can benefit substantially from a richer conceptualization of the entrepreneur that is not limited to a certain position or title, but recognizes the potential that entrepreneurial insight and creativity can be provided by all individuals in the organization. A subjectivist theory of entrepreneurship embraces a key proposition from resource learning theory: 'Managing involves a[n entrepreneurial] discovery procedure in which heterogeneous mental models of managers using heterogeneous firm-specific resources are involved in an ongoing competition' (Mahoney, 1995, p. 97).

Further, we see merit in researching the sources of knowledge-based resources that spur entrepreneurial renewal. Unlike the services of property-based resources, which are typically most economically valuable in stable environments, knowledge-based resources (e.g. creative and coordinative skills) can be most useful in unpredictable environments to maintain flexibility and adaptation. One can distinguish between experiences leading to tacit knowledge versus experiences leading to explicit/codified knowledge. It is also useful to distinguish specific versus general knowledge (Hayek, 1945), where specificity of the entrepreneur's knowledge with respect to time and place matter in more fully understanding the origins and 
Y. Y. Kor et al.

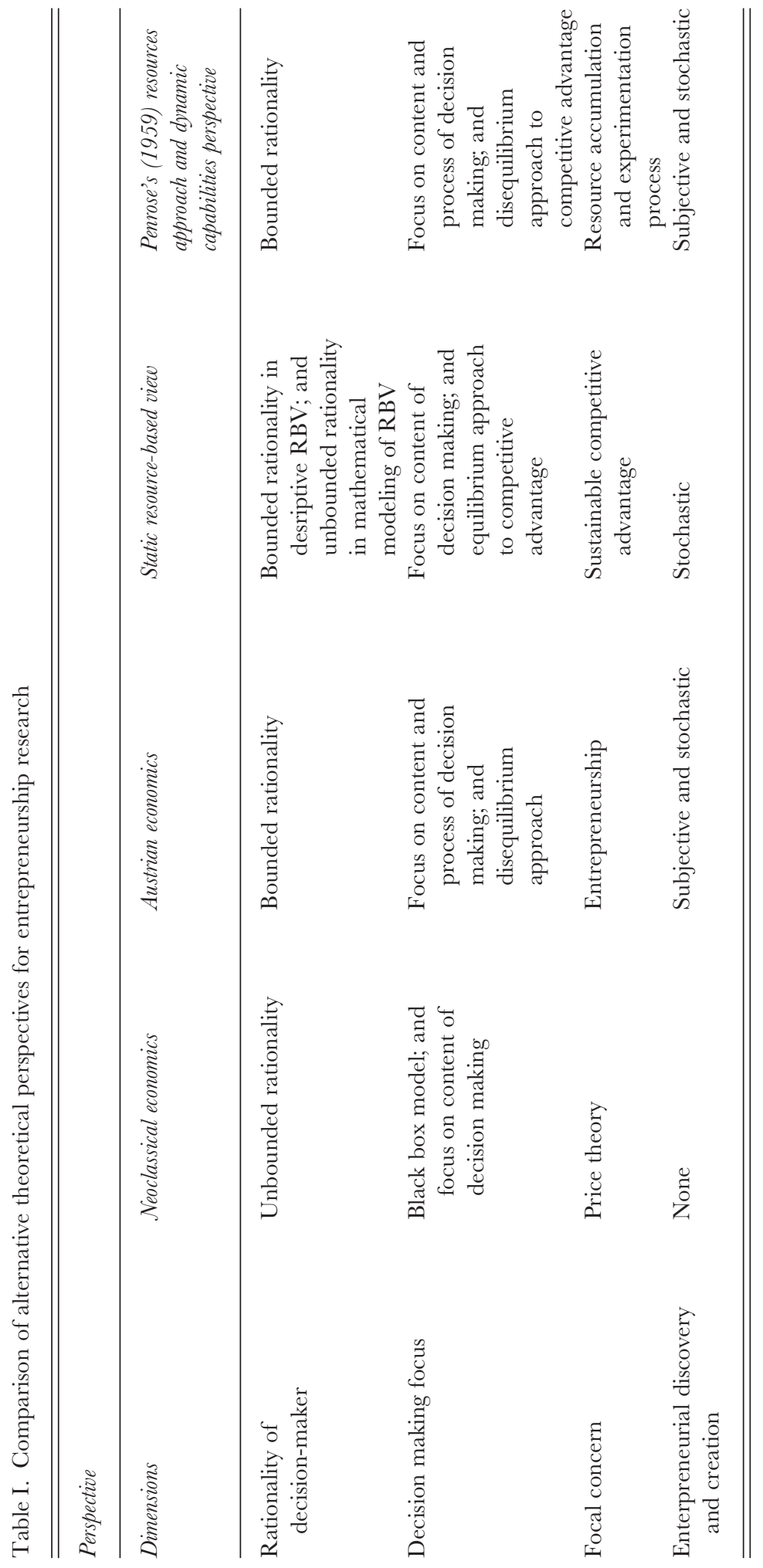


evolution of subjective entrepreneurial perceptions. For example, systemic knowledge-based resources such as coordinative and team-based capabilities tend to have high asset specificity compared to discrete knowledge-based resources such as functional and creative skills (Miller and Shamsie, 1996). The specificity of the knowledge-based resource may limit the scope of this resource's application while increasing the difficulty of its imitation (Kor and Leblebici, 2005).

In addition, future management research studies can examine how human and social capital of entrepreneurs influence the subjective productive opportunity set. The first phase of this examination involves a study of how the subjective opportunity set of a person comes about. The second phase would be to develop a theory concerning how a team can create a subjective opportunity set. Interdisciplinary research, examining psychological processes by which entrepreneurial opportunities are evaluated for their economic potential, or noting that what individuals perceive is to some extent influenced by social interactions and social forces, would be promising approaches. This research would also reveal how an entrepreneurial firm can change or renew the subjective productive opportunity of the team by adding and subtracting members to the founding team.

Such research may require a diverse set of methodological techniques. Thoughtful histories are likely to be helpful (Schumpeter, 1991 [1947]). Histories and taxonomies are reasonable beginnings for a new direction of analysis; indeed, it is how most sciences begin. Narrative, textual, and rhetorical analysis can also help us to more fully understand the versatile and ambiguous use of linguistics by organizational actors to verbalize entrepreneurial activities (Lado et al., 2006). However, an historical approach is not sufficient to produce empirical statistical significance; therefore, some technique of aggregation, such as multi-level methods or meta-analysis, may be essential.

Furthermore, we argued that entrepreneurs' subjective knowledge and intuition are strongly shaped by their experiences within the firm, the team, and the business environment. Essentially, we subscribe to a pragmatic theory of knowledge where the content of knowledge and the process of learning (i.e. knowledge acquisition) are inextricably intertwined (Mahoney, 1995). We further argue that many other forms of business experience can also notably influence managerial perceptions of viable alternatives concerning strategy development and entrepreneurial renewal. Managers' past assignments in international business contexts, for example, can shape their intuition and imagination about future growth opportunities for the firm as well as their capability to pursue these entrepreneurial opportunities successfully (Carpenter et al., 2001; Tan and Mahoney, 2006). For better or worse, past strategy-specific experiences such as experience with alliances, mergers and acquisitions, diversification, and down-scoping influence managers' inclination to adopt such strategies in their current firms (Carpenter et al., 2004). Thus, studying the past individual and shared experiences of managers can be fundamental in understanding a firm's current entrepreneurial choices. Alternatively, one can study managers' past and current experiences with specific resource bundles, strategies, markets, technologies, and stakeholders to predict a firm's future directions and patterns of growth. Uncovering the complex origins of subjective managerial perceptions, beliefs, value systems, mental models, and heuristics would help us to more fully understand the conditions that may nurture entrepreneurial creativity and/or cognitive 
biases in decision making (Adner and Helfat, 2003; Amit and Schoemaker, 1993; Huff, 1990).

Future entrepreneurship research could also productively utilize Penrose's (1959) theoretical insight concerning the distinction between resources and the services of these resources, where resources are static while their services are dynamic and specific to the task at hand. Resources can be applied in multiple ways (Itami and Roehl, 1987). A resource that substantially contributes to a firm-level capability may provide economically valuable reputational capital to attract investors, particularly in smaller firms. Past research has focused largely on the acquisition and protection of resources, but for the most part has neglected managerial processes that lead to the creation of new resource combinations for current and future product applications. The heterogeneity of managers means that no two firms have the same set of perceived opportunities. Future research can examine firm-level heterogeneity with respect to accumulating and leveraging resources and to matching the services of these resources to the emerging entrepreneurial opportunities in the environment. We suggest that there are at least five major sources of entrepreneurial success that merit future research: the individual, the entrepreneurial team, the entrepreneurial opportunity, the business environment, and the (dynamic) fit among these factors.

It is important to note that a subjectivist approach examines whether a firm is utilizing efficiently and effectively opportunities within its subjective productive opportunity set. Essentially, subjectivism suggests that a critical comparison for the firm is the comparison to its own potential. Thus, one would ask whether firms are successfully utilizing their opportunities within their set, or whether such opportunities enable the firm to attract resources from capital or labour markets, and create wealth for individuals, the firm, customers, or society.

Firms are the collective experiences of individuals, both managers and other employees, so looking inside the firm to examine the knowledge structures of individuals is required. At the same time, entrepreneurship is the pursuit of opportunity regardless of resources currently controlled (Stevenson and Gumpert, 1985). The entrepreneur uses relationships at a personal level or forms alliances at the firm level to secure resources to take advantage of opportunities. The unit of analysis might be the firm, but should not be confined to the firm; analysis should consider individuals, networks, alliances, and even friendships.

In conclusion, we anticipate that better integration of entrepreneurship and strategic management research literatures will contribute greatly to the evolving science of organization (Hitt et al., 2001; Ireland et al., 2003; Roberts and Eisenhardt, 2003). ${ }^{[10]}$ We can do better. Bringing together strategic management and entrepreneurship research can enable us to advance a dynamic and integrated subjectivist theory of how entrepreneurship functions for individuals, for firms, and for the economy at large.

\section{NOTES}

*We thank Professors Rajshree Agarwal, Sharon Alvarez, Asli Arikan, Mie Augier, Elaine Mosakowski, J-G. Spender and David Teece, as well as participants at the Ohio State Conference on Entrepreneurship (October 2005) for their comments on earlier versions of this paper. The usual disclaimer applies. 
[1] While the current paper emphasizes the conventional view of Schumpeter's (1934) admiration of the entrepreneur, we note here that Langlois (2003) documents the tension between the Schumpeter who came to praise entrepreneurship and the Schumpeter who came to bury entrepreneurship.

[2] Spiegel (1991) identifies Cantillon (1931), Say (1964), and Mill (1848) as the most influential economists introducing entrepreneurship as the fourth factor of production beyond land, labour and capital. Knight (1921) articulates that the economic return to land (i.e. fixed factors of production) is rent, the economic return to labour is wage, the economic return to capital is interest, and the economic return to entrepreneurship is economic profit, which can only exist if uncertainty exists.

[3] We thank Professor Elaine Mosakowski for bringing connections between Austrian economics and existentialist philosophy to our attention. The existentialist position is an uncomfortable one since there is full awareness of the possibility of unintended consequences of action, and simultaneously the sense of responsibility that one is still called to make decisions (and to act) under conditions of irreducible uncertainty (Arrow, 1974). We hasten to add that in a 'kaleidic' society, while the future is unknowable it is not necessarily unimaginable (Lachmann, 1976, p. 59). Mises stated that: 'Everyone carries a part of society on his shoulders: no one is relieved of his share of responsibility by others and no one can find a safe way for himself if society is sweeping towards destruction. Thus, everyone must thrust himself vigorously into the intellectual battle. No one can stand aside with unconcern: the interests of everyone hang on the result. Whether he chooses or not, every man is drawn into the great historical struggle, the decisive battle into which our epoch has plunged us' (see Herbener, 1991, p. 33).

[4] It is worth noting Hayek's remark that: 'every important advance in economic theory during the last hundred years was a further step in the consistent application of subjectivism' (1955, p. 31).

[5] The critically important case of technological innovation helps illustrate the process of organizational learning and the substantial business role of institutional entrepreneurship (Garud et al., 2002). Technology can be viewed as a set of pieces of knowledge: some in products, some in journals, some in manuals, and some within individuals. Knowledge is typically organized into 'paradigms', which are defined as patterns of solutions to specific technical problems with specific principles and technologies (Dosi, 1982). These knowledge-based paradigms provide stability on the knowledge within a firm (Patel and Pavitt, 1997). As a result, firms tend to search for technological opportunities in areas in which these firms and their entrepreneurs currently possess some knowledge and experience (Brusoni et al., 2001). Conversely, firms sometimes engage in technological research to learn about new technical opportunities within an environment of institutional constraints (Hwang and Powell, 2005).

[6] Such perceptions by entrepreneurs may, however, be subject to systematic biases in decision-making under uncertainty (Busenitz and Barney, 1997; Camerer and Lovallo, 1999; Kahneman et al., 1982).

[7] Leibenstein $(1978$, p. 72) supports the view of a subjective productive opportunity set and argues further that there are three main reasons why there does not exist a one-to-one correspondence between sets of inputs and outputs: (1) labour contracts are incomplete; (2) the production function is not completely specified or known; and (3) there is not economic trading in all factor markets. To these ideas we add that given the premise of a world where there is a subjective productive opportunity set provides the foundation enabling a resource-based theory to be developed in which entrepreneurship has a distinct and critical role. Because there is no one-to-one correspondence between inputs and outputs, entrepreneurial perceptions come to the foreground of both entrepreneurship and resourcebased theory.

[8] It is important to note here that even when entrepreneurs cannot sell their judgment, that fact alone is not sufficient to claim that these entrepreneurs cannot make use of markets to profit economically from their entrepreneurial judgments via multiple contractual relationships. Thus, Langlois states that: 'Contrary to what [others and I] may have said or implied in the past [Foss, 1993; Foss, 1996; Foss and Klein, 2005; Langlois and Cosgel, 1993], however, the non-contractibility of judgment is not a sufficient explanation for the firm in Coase's [1937] sense' (Langlois, 2007, p. 15). Furthermore, in a world of bounded rationality, which includes not only informational problems but also individuals with heterogeneous conceptual schema, the fundamental problems go well beyond moral hazard, adverse selection and other forms of opportunism (Hsieh et al., 2007) to include the costs of teaching and persuasion, which Langlois (1992) refers to as dynamic transaction costs. Langlois (2007, p. 17) observes that: 'the problem of selling a genuinely new idea is not that someone else is likely to steal it, but that no one else is likely to believe it' (see also Silver, 1984, p. 17).

[9] Langlois states that: 'Kirzner is about discovery, about alertness to new opportunities; Knight is about evaluation, about the facility of judgment in economic organization; and Schumpeter is of course about exploitation, about the carrying out of new combinations and the creative destruction that often results' (Langlois, 2007, p. 4). 
[10] In fact, as the current paper has argued, Austrian economics literature on entrepreneurship highly influenced Penrose (1959). Indeed, Edith Penrose's dissertation advisor at John Hopkins University was the Austrian economist Fritz Machlup whose doctoral dissertation advisor was Ludwig von Mises. Penrose (1959), in turn, influenced the development of dynamic resource based theory in strategic management (Kor and Mahoney, 2000, 2004; Mahoney, 2005). The conclusion of the current paper suggests that we have come full circle with contemporary resource-based theory contributing to current entrepreneurship research. We thank Professor Asli Arikan for suggesting this idea to us.

\section{REFERENGES}

Adner, R. and Helfat, G. E. (2003). 'Corporate effects and dynamic managerial capabilities'. Strategic Management fournal, 24, $1011-25$.

Ahuja, G. and Lampert, C. M (2001). 'Entrepreneurship in the large corporations: a longitudinal study of how established firms create breakthrough innovations'. Strategic Management fournal, 22, 521-44.

Allison, G. T. (1971). Essence of Decision: Explaining the Cuban Missile Crisis. Boston, MA: Little Brown and Company.

Alvarez, S. A. and Barney, J. B. (2000). 'Entrepreneurial capabilities: a resource-based view'. In Meyer, G. D. and Heppard, K. (Eds), Entrepreneurship as Strategy: Competing on the Entrepreneurial Edge. Thousand Oaks, CA: Sage, 63-81.

Alvarez, S. A. and Barney, J. B. (2002). 'Resource-based theory and the entrepreneurial firm'. In Hitt, M. A., Ireland, R. D. M., Camp, S. M. and Sexton, D. L. (Eds), Strategic Entrepreneurship: Creating a New Mindset. Oxford: Basil Blackwell, 89-105.

Alvarez, S. A. and Barney, J. B. (2004). 'Organizing rent generation and appropriation: toward a theory of the entrepreneurial firm'. Fournal of Business Venturing, 19, 621-35.

Alvarez, S. A. and Busenitz, L. W. (2001). 'The entrepreneurship of resource-based theory'. Fournal of Management, 27, 755-75.

Alvarez, S. A., Agarwal, R. and Sorenson, O. (Eds) (2005). Handbook of Entrepreneurship Research: Disciplinary Perspectives. New York: Springer.

Amit, R. and Schoemaker, P.J. (1993). 'Strategic assets and organizational rent'. Strategic Management Fournal, 14, 33-46.

Amit, R., Glosten, L. and Mueller, E. (1990). 'Entrepreneurial ability, venture investments and risk sharing'. Management Science, 36, 1232-45.

Amit, R., Glosten, L. and Mueller, E. (1993). 'Challenges to theory development in entrepreneurship research'. Fournal of Management Studies, 30, 815-34.

Andrews. K. (1980). The Concept of Corporate Strategy. New York: McGraw-Hill.

Ardichvili, A., Cardozo, R. and Ray, S. (2003). 'A theory of entrepreneurial opportunity, identification and alertness'. Fournal of Business Venturing, 19, 637-58.

Arrow, K. J. (1974). The Limits of Organization. New York: W. W. Norton.

Arthur, W. B. (1994). Increasing Returns and Path Dependence in the Economy. Ann Arbor, MI: University of Michigan Press.

Audretsch, D. B. (1995). Innovation and Industry Evolution. Cambridge, MA: MIT Press.

Audretsch, D. B. and Keilbach, M. (2007). 'The theory of knowledge spillover entrepreneurship'. Fournal of Management Studies, 44, 1242-54.

Barnard, C. A. (1938). The Functions of the Executive. Cambridge, MA: Harvard University Press.

Barney, J. B. (1991). 'Firm resources and sustained competitive advantage'. Fournal of Management, 17, 99-120.

Barr, P. S., Stimpert, J. L. and Huff, A. S. (1992). 'Cognitive change, strategic action, and organizational renewal'. Strategic Management fournal, 13, 15-36.

Barreto, H. (1989). The Entrepreneur in Microeconomic Theory: Disappearance and Explanation. New York: Routledge.

Barringer, B. R. and Bluedorn, A. C. (1999). 'The relationship between corporate entrepreneurship and strategic management'. Strategic Management fournal, 20, 421-44.

Barzel, Y. (1987). 'The entrepreneur's reward for self-policing'. Economic Inquiry, 25, 103-16.

Baumol, W.J. (1978). 'Entrepreneurship in economic theory'. American Economic Review, 58, 64-71.

Baumol, W. J. (1990). 'Entrepreneurship, productive, unproductive and destructive'. Fournal of Political Economy, 98, 893-919.

Baumol, W. J. (1993). 'Formal entrepreneurship theory in economics: existence and bounds'. Fournal of Business Venturing, 8, 197-210. 
Bercovitz, J. (1999). The Structure of Franchise Contracting. Doctoral dissertation, University of California, Berkeley.

Boettke, P.J. (2002). 'Information and knowledge: Austrian economics in search of its uniqueness'. Review of Austrian Economics, 15, 263-74.

Boulding, K. E. (1956). The Image. Ann Arbor, MI: University of Michigan Press.

Boulding, K. E. (1966). 'The economics of knowledge and the knowledge of economics'. American Economic Review, 56, 1-13.

Bourgeois, L. J. III and Eisenhardt, K. M. (1988). 'Politics of strategic decision making in high-velocity environments: toward a midrange theory'. Academy of Management fournal, 31, 737-70.

Brusoni, S., Prencipe, A. and Pavitt, K. (2001). 'Knowledge specialization, organization coupling and the boundaries of the firm: why do firms know more than they make?'. Administrative Science Quarterly, 46, 597-621.

Buchanan, J. M. and Di Pierro, A. (1980). 'Cognition, choice and entrepreneurship'. Southern Economic fournal, 46, 693-701.

Buchanan, J. M. and Vanberg, V.J. (1991). 'The market as a creative process'. Economics and Philosophy, 7, $167-86$.

Bull, I. and Willard, G. (1993). 'Towards a theory of entrepreneurship'. Fournal of Business Venturing, 8, 183-96.

Busenitz, L. W. (1996). 'Research on entrepreneurial alertness'. Fournal of Small Business Management, 34, $35-44$.

Busenitz, L. W. and Barney, J. B. (1997). 'Biases and heuristics in strategic decision-making: differences between entrepreneurs and managers in large organizations'. Fournal of Business Venturing, 12, 9-30.

Bygrave, W. B. (1998). 'Building an entrepreneurial economy'. Business Strategy Review, 9, 11-18.

Camerer, C. and Lovallo, D. (1999). 'Overconfidence and excess entry: an experimental approach'. American Economic Review, 89, 306-18.

Cantillon, R. (1931). Essay on the Nature of Commerce, originally published in 1755. London: Macmillan.

Caplan, B. (1999). 'The Austrian search for realistic foundations'. Southern Economic Fournal, 65, 823-38.

Carpenter, M. A., Sanders, W. G. and Gregersen, H. B. (2001). 'Bundling human capital with organizational context: the impact of international assignment experience on multinational firm performance and CEO pay'. Academy of Management Foumal, 44, 493-512.

Carpenter, M. A., Geletkanycz, M. A. and Sanders, W. G. (2004). 'Upper-echelons research revised: antecedents, elements, and consequences of top management team composition'. Fournal of Management, 30, 749-79.

Casson, M. (1982). The Entrepreneur: An Economic Theory. Oxford: Martin Robertson.

Casson, M. and Godley, A. (2007). 'Revisiting the emergence of the modern business enterprise: entrepreneurship and the Singer Global Distribution System’. Fournal of Management Studies, 44, 1064-77.

Chandler, G. N. and Hanks, S. H. (1994). 'Market attractiveness, resource-based capabilities, venture strategies and venture performance'. Fournal of Business Venturing, 9, 331-50.

Choi, Y. R. and Shepherd, D. A. (2004). 'Entrepreneurs' decisions to exploit opportunities'. Fournal of Management, 30, 377-95.

Coase, R. H. (1937). 'The nature of the firm'. Economica, 4, 386-405.

Cohen, W. M. and Levinthal, D. (1990). 'Absorptive capacity: a new perspective on learning and innovation'. Administrative Science Quarterly, 35, 128-52.

Cole, A. H. (1978). 'Meso-economics: a contribution from entrepreneurial history'. Explorations in Entrepreneurial History, 6, 3-33.

Conner, K. R. and Prahalad, C. K. (1996). 'A resource-based theory of the firm: knowledge versus opportunism'. Organization Science, 7, 477-501.

Cooper, A. C., Gimeno, F. J. and Woo, C. Y. (1994). 'Initial human and financial capital as predictors of new venture performance'. Fournal of Business Venturing, 9, 371-95.

Cyert, R. M. and March, J. G. (1963). A Behavioral Theory of the Firm. Englewood Cliffs, NJ: Prentice-Hall.

Daily, C., McDougall, P. P., Govin, J. G. and Dalton, D. R. (2002). 'Governance and strategic leadership in entrepreneurial firms'. Journal of Management, 28, 387-412.

Deeds, D. L., DeCarolis, D. and Coombs, J. (2000). 'Dynamic capabilities and new product development in high technology ventures: an empirical analysis of new biotechnology firms'. Fournal of Business Venturing, 15, 221-9.

Demsetz, H. (1983). 'The neglect of the entrepreneur'. In Ronen, J. (Ed.), Entrepreneurship. Lexington, MA: Lexington Press, 271-80. 
Dierickx, I. and Cool, K. (1989). 'Asset stock accumulation and sustainability of competitive advantage'. Management Science, 35, 1504-11.

Dosi, G. (1982). 'Technological paradigms and technological trajectories: a suggested interpretation of the determinants and directions of technical change'. Research Policy, 11, 147-62.

Dulbecco, P. and Garrouste, P. (1999). 'Towards and Austrian theory of the firm'. Review of Austrian Economics, 11, 43-64.

Eisenhardt, K. M. and Schoonhoven, C. B. (1990). 'Organizational growth: linking founding team, strategy, and growth among U.S. semi-conductor ventures, 1978-1988'. Administrative Science Quarterly, 35, 504-29.

Eliasson, G. (1990). 'The firm as a competent team'. Fournal of Economic Behavior and Organization, 13, 275-98.

Finkelstein, S. and Hambrick, D. C. (1996). Strategic Leadership: Top Executives and Their Effects on Organizations. St Paul, MN: West Publishing Company.

Foss, N. J. (1993). 'More on Knight and the theory of the firm'. Managerial and Decision Economics, 14, 269-76.

Foss, N. J. (1994). 'The theory of the firm: the Austrians as precursors and critics of contemporary theory'. Review of Austrian Economics, 7, 31-64.

Foss, N. J. (1996). 'The "alternative" theories of Knight and Coase, and the modern theory of the firm'. Fournal of the History of Economic Thought, 18, 76-95.

Foss, K. and Foss, N. J. (2005). 'Resources and transaction costs: how property rights economics furthers the resource-based view'. Strategic Management Fournal, 26, 541-53.

Foss, N. J. and Klein, P. G. (2005). 'Entrepreneurship and the economic theory of the firm: any gains from trade?'. In Alvarez, S. A., Agarwal, R. and Sorenson, O. (Eds), Handbook of Entrepreneurship Research: Disciplinary Perspectives. New York: Springer, 55-80.

Foss, K., Foss, N. J., Klein, P. G. and Klein, S. K. (2007). 'The entrepreneurial organization of heterogeneous capital'. Foumal of Management Studies, 44, 1165-86.

Garud, R., Jain, S. and Kumaraswamy, A. (2002). 'Institutional entrepreneurship in the sponsorship of common technological standards: the case of Sun Microsystems and Java'. Academy of Management Journal, 45, 196-214.

Geletkanycz, M. A. and Black, S. S. (2001). 'Bound by the past? Experience-based effects on commitment to the strategic status quo'. Fournal of Management, 27, 3-21.

George, G. (2000). 'Development and financial institutions as catalysts of entrepreneurship in emerging economies'. Academy of Management Reviere, 25, 620-9.

Gifford, S. (1992). 'Allocation of entrepreneurial alertness'. Fournal of Economic Behavior and Organization, 19, 265-83.

Gifford, S. (1998). 'Limited entrepreneurial attention and economic development'. Small Business Economics, 10, $17-30$.

Goodman, P. S. and Leyden, D. P. (1991). 'Familiarity and group productivity'. Fournal of Applied Psychology, 76, 578-86.

Hagedoorn, J. (1996). 'Innovation and entrepreneurship: Schumpeter revisited'. Industrial and Corporate Change, 5, 883-96.

Hambrick, D. C. (1995). 'Fragmentation and the other problems CEOs have with their top management teams'. California Management Review, 37, 110-27.

Hambrick, D. C., Geletkanycz, M. A. and Fredrickson, J. W. (1993). 'Top executive commitment to the status quo: some tests of its determinants'. Strategic Management Fournal, 14, 401-18.

Harris, D. and Helfat, C. (1997). 'Specificity of CEO human capital and compensation'. Strategic Management Fournal, 18, 895-920.

Hayek, F. A. (1945). 'The use of knowledge in society'. American Economic Revierw, 35, 519-30.

Hayek, F. A. (1948). Individualism and Economic Order. Chicago, IL: Chicago University Press.

Hayek, F. A. (1955). The Counter Revolution of Science. New York: Free Press.

Hayek, F. A. (1968). 'Competition as a discovery procedure'. Translated by Snow, M. S. Quarterly Fournal of Austrian Economics, 5, 9-23.

Hayek, F. A. (1978). 'Competition as a discovery procedure'. In New Studies in Philosophy, Politics, Economics and the History of Ideas. London: Routledge and Kegan Paul, 179-90.

Herbener, J. (1991). 'Ludwig von Mises and the Austrian school of economics'. Review of Austrian Economics, 5, 33-50.

Hitt, M. A., Ireland, R. D., Camp, S. M. and Sexton, D. L. (2001). 'Strategic entrepreneurship: entrepreneurial strategies for wealth creation'. Strategic Management Journal, 22, 479-92.

Holcombe, R. G. (2003). 'Progress and entrepreneurship'. Quarterly Fournal of Austrian Economics, 6, 3-26.

Hsieh, C., Nickerson, J. A. and Zenger, T. (2007). 'Opportunity discovery, problem solving, and the entrepreneurial theory of the firm'. Fournal of Management Studies, 44, 1255-77. 
Huff, A. S. (1990). 'Mapping strategic thought'. In Huff, A. S. (Ed.), Mapping Strategic Thought. New York: Wiley, 11-49.

Hwang, H. and Powell, W. W. (2005). 'Institutions and entrepreneurship'. In Alvarez, S. A., Agarwal, R. and Sorenson, O. (Eds), Handbook of Entrepreneurship Research: Disciplinary Perspectives. New York: Springer, 201-32.

Ionnanides, S. (1999). 'Towards an Austrian perspective on the firm'. Review of Austrian Economics, 11, 77-98.

Ireland, R. D., Hitt, M. A. and Simon, D. G. (2003). 'A model of strategic entrepreneurship: the construct and its dimensions'. Fournal of Management, 29, 963-89.

Itami, H. and Roehl, T. (1987). Mobilizing Invisible Assets. Cambridge, MA: Harvard University Press.

Jacobides, M. G. and Winter, S. G. (2007). 'Entrepreneurship and firm boundaries: the theory of a firm'. Fournal of Management Studies, 44, 1213-41.

Jacobson, R. (1992). 'The "Austrian" school of strategy'. Academy of Management Review, 17, 782-807.

Janis, I. L. (1972). Victims of Groupthink: A Psychological Study of Foreign-Policy Decisions and Fiascoes. Boston, MA: Houghton Mifflin Company.

Kahneman, D., Slovic, P. and Tversky, A. (1982). Judgment under Uncertainty: Heuristics and Biases. Cambridge, MA: Cambridge University Press.

Kaish, S. and Gilad, B. (1991). 'Characteristics of opportunities search of entrepreneurs versus executives: sources, interests, and general alertness'. Fournal of Business Venturing, 6, 45-81.

Kerr, J. L. and Jackofsky, E. F. (1989). 'Aligning managers with strategies: management development versus selection'. Strategic Management Fournal, 10, 157-70.

Kirzner, I. M. (1973). Competition and Entrepreneurship. Chicago, IL: University of Chicago Press.

Kirzner, I. M. (1979). Perception, Opportunity, and Profit: Studies in the Theory of Entrepreneurship. Chicago, IL: University of Chicago Press.

Kirzner, I. M. (1997). 'Entrepreneurial discovery and the competitive market process: an Austrian approach'. Fournal of Economic Literature, 35, 60-85.

Klein, P. G. (1999). 'Entrepreneurship and corporate governance'. Quarterly Fournal of Austrian Economics, 2, $19-42$.

Klein, P. G. and Klein, S. K. (2001). 'Do entrepreneurs make predictable mistakes? Evidence from corporate divestitures'. Quarterly Fournal of Austrian Economics, 4, 3-25.

Knight, F. H. (1921). Risk, Uncertainty and Profit. Chicago, IL: University of Chicago Press.

Kogut, B. and Zander, U. (1992). 'Knowledge of the firm, combinative capabilities, and the replication of technology'. Organization Science, 3, 383-97.

Kor, Y. Y. (2003). 'Experience-based top management team competence and sustained growth'. Organization Science, 14, 707-19.

Kor, Y. Y. and Leblebici, H. (2005). 'How do interdependencies among human-capital deployment, development, and diversification strategies affect firms' financial performance?'. Strategic Management Fournal, 26, 967-85.

Kor, Y. Y. and Mahoney, J. T. (2000). 'Penrose's resource-based approach: the process and product of research creativity'. Fournal of Management Studies, 37, 109-39.

Kor, Y. Y. and Mahoney, J. T. (2004). 'Edith Penrose's (1959) contributions to the resource-based view of the firm'. Fournal of Management Studies, 41, 183-91.

Kor, Y. Y. and Mahoney, J. T. (2005). 'How dynamics, management, and governance of resource deployments influence firm-level performance'. Strategic Management Fournal, 26, 489-96.

Lachmann, L. M. (1976). 'From Mises to Shackle: an essay on Austrian economics and the kaleidic society'. Fournal of Economic Literature, 14, 54-62.

Lachmann, L. M. (1986). The Market as an Economic Process. Oxford: Blackwell.

Lado, A., Boyd, N., Wright, P. and Kroll, M. (2006). 'Paradox and theorizing within the resource-based view'. Academy of Management Revierw, 31, 115-31.

Langlois, R. N. (1992). 'Transaction-cost economics in real time'. Industrial and Corporate Change, 1, 99-127.

Langlois, R. N. (2003). 'Schumpeter and the obsolescence of entrepreneurship and the entrepreneur'. Advances in Austrian Economics, 6, 287-302.

Langlois, R. N. (2007). 'The entrepreneurial theory of the firm and the theory of the entrepreneurial firm'. Fournal of Management Studies, 44, 1107-24.

Langlois, R. N. and Cosgel, M. (1993). 'Frank Knight on risk, uncertainty, and the firm: a new interpretation'. Economic Inquiry, 31, 456-65.

Leff, N. A. (1979). 'Entrepreneurship and economic development: the problem revisited'. Fournal of Economic Literature, 17, 46-64.

Leibenstein, H. (1978). 'The entrepreneur in economic history'. American Economic Review, 58, 72-83. 
Lewin, P. (2001). 'The development of Austrian economics: revisiting the neoclassical divide'. Review of Austrian Economics, 14, 239-50.

Lewin, P. and Phelan, S. E. (1999). 'Firms, strategies and resources: contributions from Austrian economics'. Quarterly Fournal of Austrian Economics, 2, 3-18.

Loasby, B. J. (1976). Choice, Complexity, and Ignorance. Cambridge: Cambridge University Press.

Loasby, B. J. (2002). 'The significance of Penrose's theory for the development of economics'. In Pitelis, C. (Ed.), The Growth of the Firm: The Legacy of Edith Penrose. Oxford: Oxford University Press, 45-59.

Low, M. and MacMillan, I. (1988). 'Entrepreneurship: past research and future challenges'. Fournal of Management, 14, 139-61.

Machlup, F. (1982). 'Austrian economics'. In Greenwald, D. (Ed.), Encyclopedia of Economics. New York: McGraw-Hill, 38-43.

Mahoney, J. T. (1995). 'The management of resources and the resource of management'. Fournal of Business Research, 33, 91-101.

Mahoney, J. T. (2005). Economic Foundations of Strategy. Thousand Oaks, CA: Sage.

Mahoney, J. T. and Michael, S. C. (2005). 'A subjectivist theory of entrepreneurship'. In Alvarez, S. A., Agarwal, R. and Sorenson, O. (Eds), Handbook of Entrepreneurship. Boston, MA: Kluwer, 33-53.

Mahoney, J. T. and Pandian, J. R. (1992). 'The resource-based view within the conversation of strategic management'. Strategic Management fournal, 13, 363-80.

Malmgren, H. B. (1961). 'Information, expectations and the theory of the firm'. Quarterly fournal of Economics, 75, 399-421.

March, J. G. and Simon, H. A. (1958). Organizations. New York: John Wiley.

McDougall, P. and Oviatt, B. (2000). 'International entrepreneurship: the intersection of two research paths'. Academy of Management Fournal, 43, 902-8.

McGrath, R. G. (1995). 'Advantage from adversity: learning from disappointment in internal corporate ventures'. Fournal of Business Venturing, 9, 351-69.

McGrath, R. G. (2001). 'Exploratory learning, innovative capacity, and managerial oversight'. Academy of Management Fournal, 44, 118-31.

Menger, C. (1985). Principles of Economics, originally published in 1871. New York: New York University Press.

Metcalfe,J. S. (2004). 'The entrepreneur and the style of modern economics'. Foumal of Evolutionary Economics, 14, 157-75.

Michael, S. C. (2000). 'Investments to create bargaining power. The case of franchising'. Strategic Management fournal, 21, 487-514.

Mill, J. S. (1848). Principles of Political Economy, 7th edition. London: Longman Green and Company.

Miller, D. and Shamsie, J. (1996). 'The resource-based view of the firm in two environments: the Hollywood film studios from 1936 to 1965'. Academy of Management fournal, 39, 519-43.

Minniti, M. (2004). 'Entrepreneurial alertness and asymmetric information in a spin-glass model'. Fournal of Business Venturing, 19, 637-58.

Mises, L. (1998). Human Action: A Treatise on Economics, originally published in 1949. Auburn, AL: Ludwig von Mises Institute.

Mosakowski, E. (1993). 'A resource-based perspective on the dynamic strategy-performance relationship: an empirical examination of the focus and differentiation strategies in entrepreneurial firms'. Fournal of Management, 19, 819-39.

Mosakowski, E. (1998). 'Entrepreneurial resources, organizational choices, and competitive outcomes'. Organization Science, 9, 625-43.

Mosakowski, E. (2002). 'Overcoming resource-disadvantages in entrepreneurial firms: when less is more'. In Hitt, M. A., Ireland, R. D. and Sexton, D. L. (Eds), Strategic Entrepreneurship: Creating a New Mindset. Oxford: Basil Blackwell, 106-26.

Nelson, R. R. and Winter, S. G. (1982). An Evolutionary Theory of Economic Change. Cambridge, MA: Harvard University Press, The Belknap Press.

North, D. G. (1990). Institutions, Institutional Change and Economic Performance. Cambridge: Cambridge University Press.

O'Driscoll, G. P. P. (1977). Economics as a Coordination Problem. Kansas City, MI: Sheed Andrews and McMeed, Inc.

O'Driscoll, G. P. O. and Rizzo, M. J. (1985). The Economics of Time and Ignorance. Oxford: Basil Blackwell.

Patel, P. and Pavitt, K. (1997). 'The technological competencies of the world's largest firms: complex and path-dependent, but not much variety'. Research Policy, 26, 141-56.

Penrose, E. T. (1959). The Theory of the Growth of the Firm. New York: John Wiley \& Sons. 
Peteraf, M. (1993). 'The cornerstones of competitive advantage'. Strategic Management Fournal, 13, 36380 .

Phan, P. H. (2004). 'Entrepreneurship theory: possibilities and future directions'. Fournal of Business Venturing, 19, 617-20.

Polanyi, M. (1962). Personal Knowledge: Towards a Post-Critical Philosophy. Chicago, IL: University of Chicago Press.

Prahalad, C. K. and Bettis, R. A. (1986). 'The dominant logic: a new linkage between diversity and performance'. Strategic Management fournal, 7, 485-501.

Prescott, E. C. and Visscher, M. (1980). 'Organizational capital'. Fournal of Political Economy, 88, $446-61$.

Priem, R. L. (1990). 'Top management team group factors, consensus, and firm performance'. Strategic Management fournal, 11, 469-78.

Richardson, G. B. (2002). 'Mrs. Penrose and neoclassical theory'. In Pitelis, C. (Ed.), The Growth of the Firm: The Legacy of Edith Penrose. New York: Oxford University Press, 37-44.

Roberts, P. W. and Eisenhardt, K. M. (2003). 'Austrian insights on strategic organization: from market insights to implications for the firm'. Strategic Organization, 1, 345-52.

Rothbard, M. N. (2004). Man, Economy and the State, originally published in 1962. Auburn, AL: Ludwig Mises Institute.

Rubin, P. H. (1973). 'The expansion of firms'. Fournal of Political Economy, 81, 936-49.

Rumelt, R. P. (1984). 'Towards a strategic theory of the firm'. In Lamb, R. B. (Ed.), Competitive Strategic Management. Englewood Cliffs, NJ: Prentice Hall, 556-70.

Rumelt, R. P. (1987). 'Theory, strategy, and entrepreneurship'. In Teece, D. (Ed.), The Competitive Challenge. Cambridge, MA: Ballinger, 137-58.

Salerno, J. T. (1993). 'Mises and Hayek dehomogenized'. Review of Austrian Economics, 6, 113-46.

Saravathy, S. D. (2004). 'The questions we ask and the questions we care about: reformulating some problems in entrepreneurship research'. Fournal of Business Venturing, 19, 707-17.

Say, J.-B. (1964). A Treatise on Political Economy, originally published in 1821. New York: Augustus M. Kelley.

Schumpeter, J. A. (1934). The Theory of Economic Development. Cambridge, MA: Harvard University Press.

Schumpeter, J. A. (1991 [1947]). 'Comments on a plan for the study of entrepreneurship'. In Swedberg, R. (Ed.), Joseph A. Schumpeter: The Economics and Sociology of Capitalism. Princeton, NJ: Princeton University Press, 406-28.

Shackle, G. L. S. (1961). Decision, Order and Time in Human Affairs. Cambridge: Cambridge University Press.

Shackle, G. L. S. (1967). The Years of High Theory. Cambridge, MA: Harvard University Press.

Shackle, G. L. S. (1972). Epistemics and Economics. Cambridge: Cambridge University Press.

Shane, S. (2000). 'Prior knowledge and the discovery of entrepreneurial opportunities'. Organization Science, 11, 448-69.

Shane, S. and Venkatraman, S. (2000). 'The promise of entrepreneurship as a field of research'. Academy of Management Review, 25, 217-26.

Shepherd, D. A. and DeTienne, D. R. (2005). 'Prior knowledge, potential financial rewards, and opportunity identification'. Entrepreneurship: Theory and Practice, 29, 91-112.

Silver, M. (1984). Enterprise and the Scope of the Firm. London: Martin Robertson.

Simon, H. A. (1947). Administrative Behavior. New York: Free Press.

Smith, K. G., Smith, K. A., Olian, J. D., Sims, H. P. Jr, O’Bannon, D. P. and Scully, J. A. (1994). 'Top management team demography and process: the role of social integration and communication'. Administrative Science Quarterly, 39, 412-38.

Sorensen, J. B. and Sorenson, O. (2003). 'From conception to birth: opportunity, perception and resource mobilization in entrepreneurship'. Advances in Strategic Management, 20, 89-117.

Spender, J-C. (1989). Industry Recipes. Oxford: Blackwell.

Spender, J-C. (1996). 'Making knowledge the basis of a theory of the firm'. Strategic Management Fournal, Winter Special Issue, 45-62.

Spiegel, H. W. (1991). The Growth of Economic Thought. Durham, NC: Duke University Press.

Stevenson, H. and Gumpert, D. (1985). 'The heart of entrepreneurship'. Harvard Business Review, 63, 85-94.

Stevenson, H. and Jarillo, J. C. (1990). 'A paradigm of entrepreneurship: entrepreneurial management'. Strategic Management Fournal, 11, 17-27.

Stuart, T. E. and Sorenson, O. (2005). 'Social networks and entrepreneurship'. In Alvarez, S. A., Agarwal, R. and Sorenson, O. (Eds), Handbook of Entrepreneurship Research: Disciplinary Perspectives. New York: Springer, 233-52.

Tan, D. and Mahoney, J. T. (2005). 'Examining the Penrose effect in an international business context: the dynamics of Japanese firm growth in U.S. industries'. Managerial and Decision Economics, 26, 113-27. 
Tan, D. and Mahoney, J. T. (2006). 'Why a multinational firm chooses expatriates: integrating resourcebased, agency, and transaction costs perspectives'. Fournal of Management Studies, 43, 457-84.

Teece, D. J. (1982). 'Towards an economic theory of the multiproduct firm'. Fournal of Economic Behavior and Organization, 3, 39-63.

Thornhill, S. and Amit, R. (2001). 'A dynamic perspective of internal fit in corporate venturing'. Fournal of Business Venturing, 16, 25-50.

Tsoukas, H. (1996). 'The firm as a distributed knowledge system: a constructionist approach'. Strategic Management Fournal, 17, 11-25.

Tushman, M. and O'Reilly, C. A. (1997). Winning through Innovation: A Practical Guide to Leading Organizational Change and Renewal. Boston, MA: Harvard Business School Press.

Vaughn, K. (1994). Austrian Economics in America: The Migration of a Tradition. Cambridge, Cambridge University Press.

Vaughn, K. (1999). 'Hayek's implicit economics: rules and the problems of order'. Review of Austrian Economics, 11, $129-44$.

Wiersema, M. F. and Bantel, K. A. (1992). 'Top management team demography and corporate strategic change'. Academy of Management fournal, 35, 91-121.

Wiklund, J. and Shepherd, D. (2003). 'Knowledge-based resources, entrepreneurial orientation, and the performance of small and medium-sized businesses'. Strategic Management Fournal, 24, 1307-14.

Witt, U. (1998). 'Imagination and leadership: the neglected dimension of an evolutionary theory of the firm'. Fournal of Economic Behavior and Organization, 35, 161-77.

Witt, U. (1999). 'Do entrepreneurs need firms? A contribution to a missing chapter in Austrian economics'. Review of Austrian Economics, 11, 99-110.

Witt, U. (2000). 'Changing cognitive frame-changing organizational forms: an entrepreneurial theory of organizational development'. Industrial and Corporate Change, 9, 733-55.

Witt, U. (2007). 'Firms as realizations of entrepreneurial visions'. Fournal of Management Studies, 44, 1125-40.

Yeager, L. B. (1987). 'Why subjectivism?'. Review of Austrian Economics, 1, 5-31.

Yeager, L. B. (1994). 'Mises and Hayek on calculation and knowledge'. Review of Austrian Economics, 7, 93-109.

Yu, T. F. (2001). 'Entrepreneurial alertness and discovery'. Review of Austrian Economics, 14, 47-63.

Zahra, S. A. (2005). 'Entrepreneurship and disciplinary research: return to the fountainhead'. In Alvarez, S. A., Agarwal, R. and Sorenson, O. (Eds), Handbook of Entrepreneurship. Boston, MA: Kluwer, 253-68.

Zahra, S. A. and Filatochev, I. (2004). 'Governing the entrepreneurial firm: a knowledge based view'. Fournal of Management Studies, 41, 885-98.

Zahra, S. A., Ireland, R. D., Gutierrez, I. and Hitt, M. A. (2000). 'Privatization and entrepreneurial transformation: emerging issues and a future research agenda'. Academy of Management Review, 25, 509-24.

Zahra, S. A., Sapienza, H. J. and Davidsson, P. (2006). 'Entrepreneurship and dynamic capabilities: a review, model and research agenda'. Fournal of Management Studies, 43, 917-55.

Zander, I. (2007). 'Do you see what I mean? An entrepreneurship perspective on the nature and boundaries of the firm'. Fournal of Management Studies, 44, 1141-64. 